\title{
Influence of Enriched Button Mushroom Spent Compost on Growth and Yield of Cabbage
}

\author{
A.R. Kedar*, T.K. Narute, S.N. Hasabnis and A.R. Potdar \\ Department of Plant Pathology and Agricultural Microbiology, College of Agriculture, Pune, \\ Mahatma Phule Krishi Vidyapeeth, Maharashtra State, India \\ *Corresponding author
}

\section{A B S T R A C T}

Ke y w or d s
Button mushroom
spent compost,
Enrichment,
Biofertilizers,
Cabbage

The investigations on Influence of enriched button mushroom spent compost on growth of cabbage were carried at Plant Pathology Section, College of Agriculture, Pune during rabi 2018. The treatment with button mushroom spent compost + Azotobacter @10 kg/ha + P.S.B @10 kg/ha + Decomposing culture@ $20 \mathrm{~kg} / \mathrm{ha}$ proved to be best among all treatments in respect to growth parameters such as root length at harvest, green weight (deheaded) and dry weight of whole plant (deheaded). Highest yield of cabbage $(1.1 \mathrm{~kg})$ and diameter of cabbage $(15.87 \mathrm{~cm})$ was recorded in this treatment. This was followed by treatment with button mushroom spent compost + Azotobacter@10 kg/ha + P.S.B. @10 kg/ha in respect to yield i.e. weight of head $(0.94 \mathrm{~kg})$ and diameter of head $(14.83 \mathrm{~cm})$. The minimum yield i.e. weight of head $(0.55 \mathrm{~kg})$ and diameter of cabbage $(11.47$ $\mathrm{cm}$ ) were recorded in control treatment i.e. without button mushroom spent compost.

\section{Introduction}

Cabbage (Brassica oleracea var. capitata L.) is one of the most important cole crops grown under temperate to tropical climate conditions in more than ninety countries throughout the world (Singh et al., 2010). The compost left after the harvest of one full crop of mushroom, beyond which extension of crop becomes unremunerative is called as the 'spent mushroom substrate' (SMS) (Ahlawat and Sagar, 2007). The growing substrates are composted from different waste materials such as sawdust, rice straw, cotton wastes, paper wastes, cocoa shells, wheat straw, maize husks and various other wastes (Jonathan et al., 2002).

During the last few years, the use of chemical fertilizers is increasing for getting higher 
production of crops. The increased use of inorganic fertilizer is causing soil pollution and lessening the productivity by causing deterioration of soil structure. The continuous and imbalanced uses of chemical fertilizers lead to decreases the nutrient uptake and adversely affect the quality of produce (Agarwal, 2003).

Button mushroom spent compost is not fully decomposed hence decomposing culture can be used to fasten the process of decomposition of spent button mushroom compost. It helps to release the nutrients from button mushroom spent compost easily.

Considering the importance and vast use of spent mushroom compost it has been decided to improve the quality of button mushroom spent compost by enriching it with biofertilizers rather using only button mushroom spent compost for cabbage production. Hence the experiment on influence of enriched button mushroom spent compost on growth of cabbage was planned.

\section{Materials and Methods}

\section{Experimental details}

The field trial was conducted at experimental field of Plant Pathology Section, College of Agriculture, Pune during rabi 2018 as detailed below.

Replications: Three (3)

Treatments: Nine (9)

Design: Randomised Block Design

Spacing: $45 \mathrm{~cm}$ X $30 \mathrm{~cm}$

Variety: Euro-2

Fertilizer dose: 160:80:80kgNPK/ha
Button mushroom spent compost application rate: $20 \mathrm{~T} /$ ha

Treatments details: as listed under table 1 and 2.

During the experiment, the observations were recorded on growth and yield parameters viz., root length at harvest, green weight and dry weight of whole plant (deheaded), diameter and the yield of cabbage head ( $\mathrm{kg}$ per plant) and analysed statically.

\section{Results and Discussion}

Green weight of whole plant (deheaded and dry matter weight of whole plant)

The green weight of deheaded whole plant was recorded immediately after harvest of head. Dry matter weight of whole plant is also recorded. The results were recorded and presented in Table 1.

\section{Green weight of whole plant (deheaded)}

The data described in Table 1 revealed that treatment $\mathrm{T}_{7}$ i.e. Button mushroom spent compost + Azotobacter @10 kg/ha + P.S.B @ $10 \mathrm{~kg} / \mathrm{ha}+$ Decomposing culture@ $20 \mathrm{~kg} / \mathrm{ha}$ had higher green weight of deheaded whole plant immediately after harvesting $(594.87 \mathrm{~g})$.

This was followed by treatment $\mathrm{T}_{6}$ i.e.button mushroom spent compost + Azotobacter@10 $\mathrm{kg} / \mathrm{ha}+$ P.S.B. @ 10 kg/ha (589.33 g). The lowest (462 g) green weight of deheaded whole plant immediately after harvesting was recorded in treatment $\mathrm{T}_{9}$ i.e. Control (without button mushroom spent compost).

The results are in conformity with work of Espiritu (2011) who reported that fresh and dry weight of pechay were significantly increased by combined inoculation of Azotobacter sp. and T. harzianum. 


\section{Dry matter weight of whole plant}

The data shown in Table 1 revealed that treatment $\mathrm{T}_{7}$ i.e. button mushroom spent compost + Azotobacter @ 10 kg/ha + P.S.B @10 kg/ha + Decomposing culture@ 20 kg/ha had higher dry matter weight of whole plant at 15 days of transplanting (74.76g) followed by treatment $\mathrm{T}_{6}$ i.e. button mushroom spent compost + Azotobacter@10 kg/ha + P.S.B. @ $10 \mathrm{~kg} / \mathrm{ha}(65.51 \mathrm{~g})$. The lowest $(51.7 \mathrm{~g})$ dry matter weight of whole plant at 15 days after transplantation was recorded in treatment $\mathrm{T}_{9}$ i.e. Control (without button mushroom spent compost). The results were parallel with findings of Espiritu (2011) who reported that fresh and dry weight of pechay were significantly increased by combined inoculation of Azotobacter sp. and $\mathrm{T}$. harzianum.

\section{Root length at harvest}

The maximum root length at harvest (17.70 $\mathrm{cm})$ was recorded in treatment $\mathrm{T}_{7}$ i.e. button mushroom spent compost + Azotobacter@10 kg/ha + P.S.B@10 kg/ha + Decomposing culture@20 kg/ha followed by treatment $\mathrm{T}_{6}$ i.e. button mushroom spent compost + Azotobacter@10 kg/ha + P.S.B. @10 kg/ha $(17.41 \mathrm{~cm})$ while minimum root length at harvest $(16.10 \mathrm{~cm})$ is recorded in treatment $\mathrm{T}_{9}$ i.e. control (without button mushroom spent compost).

Table.1 Effect of enriched button mushroom spent compost on growth of cabbage

\begin{tabular}{|c|c|c|c|c|}
\hline \multicolumn{2}{|r|}{ Treatments } & \multirow{2}{*}{$\begin{array}{c}\text { Green weight } \\
\text { (g) } \\
\text { (deheaded) } \\
482.00\end{array}$} & \multirow{2}{*}{$\begin{array}{c}\begin{array}{c}\text { Dry } \\
\text { matter } \\
\text { weight }(\mathbf{g})\end{array} \\
53.38\end{array}$} & \multirow{2}{*}{$\begin{array}{c}\begin{array}{c}\text { Root } \\
\text { length } \\
(\mathbf{c m})\end{array} \\
16.77\end{array}$} \\
\hline $\mathbf{T}_{1}$ & $\begin{array}{c}\text { Button mushroom spent compost }+ \text { Azotobacter } \\
@ 10 \mathrm{~kg} / \mathrm{ha}\end{array}$ & & & \\
\hline $\mathbf{T}_{2}$ & $\begin{array}{l}\text { Button mushroom spent compost + Phosphate } \\
\text { Solubilizing Bacteria (P.S.B.) @ } 10 \text { kg/ha }\end{array}$ & 481.33 & 52.66 & 16.67 \\
\hline $\mathbf{T}_{\mathbf{3}}$ & $\begin{array}{l}\text { Button mushroom spent compost + } \\
\text { Decomposing culture @ } 20 \mathrm{~kg} / \mathrm{ha}\end{array}$ & 472.67 & 52.05 & 16.67 \\
\hline $\mathbf{T}_{4}$ & $\begin{array}{c}\text { Button mushroom spent compost + } \\
\text { Azotobacter@10 kg/ha + Decomposing culture } \\
\text { @20 Kg/ha }\end{array}$ & 558.00 & 58.35 & 16.90 \\
\hline $\mathbf{T}_{5}$ & $\begin{array}{c}\text { Button mushroom spent compost + P.S.B. @10 } \\
\text { kg/ha + Decomposing culture @ } 20 \text { kg/ha }\end{array}$ & 504.00 & 53.91 & 16.87 \\
\hline $\mathbf{T}_{6}$ & $\begin{array}{c}\text { Button mushroom spent compost + } \\
\text { Azotobacter@10 kg/ha + P.S.B. @ } 10 \text { kg/ha }\end{array}$ & 589.33 & 65.51 & 17.41 \\
\hline $\mathbf{T}_{7}$ & $\begin{array}{c}\text { Button mushroom spent compost + Azotobacter } \\
@ 10 \mathrm{~kg} / \mathrm{ha}+\text { P.S.B @ } 10 \mathrm{~kg} / \mathrm{ha}+\text { Decomposing } \\
\text { culture@ } 20 \mathrm{~kg} / \mathrm{ha}\end{array}$ & 594.87 & 74.76 & 17.70 \\
\hline $\mathbf{T}_{8}$ & $\begin{array}{c}\text { Only Button mushroom spent compost (without } \\
\text { biofertilizers) }\end{array}$ & 470.67 & 51.9 & 16.33 \\
\hline $\mathbf{T}_{9}$ & $\begin{array}{l}\text { Control (Without button mushroom spent } \\
\text { compost) }\end{array}$ & 462.00 & 51.7 & 16.10 \\
\hline & $\operatorname{SEm}( \pm)$ & 12.65 & 2.18 & 0.41 \\
\hline & CD (5\%) & 38.25 & 6.61 & N.S. \\
\hline
\end{tabular}


Table.2 Effect of enriched button mushroom spent compost on diameter and yield of head of cabbage

\begin{tabular}{|c|c|c|c|}
\hline \multicolumn{2}{|r|}{ Treatments } & \multirow{2}{*}{$\begin{array}{c}\begin{array}{c}\text { Diameter of } \\
\text { head }(\mathbf{c m})\end{array} \\
12.80\end{array}$} & \multirow{2}{*}{$\begin{array}{c}\begin{array}{c}\text { Yield :weight } \\
\text { of head }(\mathbf{k g})\end{array} \\
0.68\end{array}$} \\
\hline $\mathbf{T}_{1}$ & $\begin{array}{c}\text { Button mushroom spent compost + Azotobacter } \\
@ 10 \mathrm{~kg} / \mathrm{ha}\end{array}$ & & \\
\hline $\mathbf{T}_{2}$ & $\begin{array}{l}\text { Button mushroom spent compost + Phosphate } \\
\text { Solubilizing Bacteria (P.S.B.) @ } 10 \mathrm{~kg} / \mathrm{ha}\end{array}$ & 12.53 & 0.62 \\
\hline $\mathbf{T}_{3}$ & $\begin{array}{l}\text { Button mushroom spent compost + Decomposing } \\
\text { culture @ } 20 \mathrm{~kg} / \mathrm{ha}\end{array}$ & 12.43 & 0.60 \\
\hline $\mathbf{T}_{4}$ & $\begin{array}{c}\text { Button mushroom spent compost + Azotobacter@10 } \\
\text { kg/ha + Decomposing culture @ } 20 \mathrm{Kg} / \mathrm{ha}\end{array}$ & 14.27 & 0.87 \\
\hline $\mathbf{T}_{5}$ & $\begin{array}{l}\text { Button mushroom spent compost + P.S.B. @ } 10 \\
\text { kg/ha + Decomposing culture @ } 20 \mathrm{~kg} / \mathrm{ha}\end{array}$ & 13.90 & 0.79 \\
\hline$T_{6}$ & $\begin{array}{l}\text { Button mushroom spent compost + Azotobacter@10 } \\
\text { kg/ha + P.S.B. @ } 10 \mathrm{~kg} / \mathrm{ha}\end{array}$ & 14.83 & 0.94 \\
\hline $\mathbf{T}_{7}$ & $\begin{array}{c}\text { Button mushroom spent compost + Azotobacter } \\
@ 10 \mathrm{~kg} / \mathrm{ha}+\text { P.S.B @ } 10 \mathrm{~kg} / \mathrm{ha}+\text { Decomposing } \\
\text { culture@ } 20 \mathrm{~kg} / \mathrm{ha}\end{array}$ & 15.87 & 1.10 \\
\hline $\mathbf{T}_{8}$ & $\begin{array}{l}\text { Only Button mushroom spent compost (without } \\
\text { biofertilizers) }\end{array}$ & 12.17 & 0.59 \\
\hline $\mathbf{T}_{9}$ & Control (Without button mushroom spent compost) & 11.47 & 0.55 \\
\hline & $\operatorname{SEm}( \pm)$ & 0.33 & 0.04 \\
\hline & CD $(5 \%)$ & 1.01 & 0.11 \\
\hline
\end{tabular}

The results obtained were comparable to the findings of Unal (2015) who reported that the values of hypocotyl length, seedling length, seedling root length, shoot fresh weight and root fresh weight of tomato gave the best results in the seedlings grown in $100 \%$ spent mushroom compost. Also, the results were similar with work of Sudjana et al.,(2017) who reported that the use of enriched compost with $\mathrm{N}$ fixing microbe and $\mathrm{P}$ solubilizing could provide better plant performance as compared to without compost or without enriched compost. In present investigation too, the crop had performed better under application of button mushroom spent compost enriched with bioinoculants as compared to treatments non-enriched $\mathrm{T}_{8}$ as well as control (without button mushroom spent compost).

\section{Yield}

The diameter of head and weight of head were noted immediately after harvest of cabbage crop. The results were recorded and presented in the Table 2.

\section{Diameter of head}

The diameter of head of cabbage was recorded at harvesting. The maximum diameter $(15.87 \mathrm{~cm})$ of head of cabbage was recorded in treatment $\mathrm{T}_{7}$ i.e. button mushroom spent compost + Azotobacter @10 kg/ha +P.S.B @ $10 \mathrm{~kg} / \mathrm{ha}+$ Decomposing culture@ $20 \mathrm{~kg} / \mathrm{ha}$ which is followed by treatment $\mathrm{T}_{6}$ i.e. button mushroom spent compost + Azotobacter@10 $\mathrm{kg} / \mathrm{ha}+$ P.S.B. @10 kg/ha $(14.83 \mathrm{~cm})$. Minimum diameter $(11.47 \mathrm{~cm})$ of head of 
cabbage was recorded in $\mathrm{T}_{9}$ i.e. Control (Without button mushroom spent compost).

The results obtained were in agreement to Ahlawat et al., (2006) who stated that SMC enhances the stalk length $(5.10 \mathrm{~cm})$, curd length $(12.25 \mathrm{~cm})$ and curd diameter (15.17 $\mathrm{cm})$ in cauliflower.

\section{Weight of head}

The highest $(1.1 \mathrm{~kg})$ yield of cabbage head was recorded in treatment $\mathrm{T}_{7}$ i.e. button mushroom spent compost + Azotobacter @10 kg/ha +P.S.B@10 kg/ha + Decomposing culture@20 kg/ha. This was followed by treatment $\mathrm{T}_{6}$ (button mushroom spent compost +Azotobacter@10 kg/ha + P.S.B. @10 kg/ha) wherein head had weighed $0.94 \mathrm{~kg}$.

Both of these treatments are statistically at par with each other. Lowest $(0.55 \mathrm{~kg})$ yield was recorded in $\mathrm{T}_{9}$ i.e. control (without button mushroom spent compost).

The results were parallel with work of Taha et al., (2018) who recorded that PGPR-bacteria + SMC (Spent Mushroom Compost) tea and $\mathrm{KH}$ (Potassium Humate) were present within the soil can reduce the requirement of nitrogen fertilizer applications and lead to higher yield of tomato.

Yildirim et al., (2009) reported that the use of the inoculant (Azotobacter + Pseudomonas) on compost used as cauliflower growing medium provided high-yield of crop and highest plant weight compared to that without enrichment or singly enrichment.

The results obtained were comparable to the findings of Ahlawat et al., (2007) who reported SMC enhances fruit yield $(71 \mathrm{q} / \mathrm{ha})$ in comparison to farm yard manure and the recommended dose of fertilizers $(52.5 \mathrm{q} / \mathrm{ha})$ in chilli. Similar findings were reported by
Sangwan et al., (2002) who got the highest yield of wheat in the treatment receiving SMC $+100 \%$ recommended dose of chemical fertilizers.

Indian agriculture needs substitute for FYM, the present experiment shows that button mushroom spent compost can be used as substitute for FYM or organic manure. The experiment was conducted to study the influence of enriched button mushroom spent compost on growth of cabbage.

It had shown how to improve the quality of button mushroom spent compost by enriching it with biofertilizers like Azotobacter, PSB and decomposing culture. The present research revealed significant results from which it can be concluded that

1. The application of button mushroom spent compost enriched with Azotobacter, PSB and decomposing culture exhibited better influence on growth parameters like root length, green weight and dry matter weight of cabbage. This enriched button mushroom spent compost showed profound influence on diameter of head and yield of cabbage crop.

\section{References}

Agarwal, 2003. Plant nutrients their function and uptake. In: Soil Fertility, theory and practices, ICAR, New Delhi. pp. $26-32$.

Ahlawat, O.P. Dev Raj, Sagar, M.P. Gupta Pradeep and Vijay B. 2006. Effect of recomposed spent mushroom substrate on yield and quality of cauliflower (Brassica oleracea L. var. botrytis). Mushroom Res. 15 (2): 149 - 152.

Ahlawat, O.P. and Sagar, M.P. 2007. Management of spent mushroom substrate. National Research Centre for Mushroom (ICAR) Chambaghat, Solan - 173213 (HP), India. 
Jonathan, S.G. 2002. Vegetative growth requirements and antimicrobial activities of some higher fungi in Nigeria [dissertation]. Ibadan: University of Ibadan.

Sangwan, P. S. Swam S. Singh, J. P. Kuhad, M. S. and Dahiya, S. S. 2002. Effect of spent mushroom compost and inorganic fertilizers on the yield and nutrient uptake by wheat. J. Indian Soc. of Soil Sci. 50 (2): 114-117.

Singh, B. K. Sharma, S. R. Kalia, P. and Singh, B. 2010. Character association and path analysis of morphology and economic traits in cabbage (Brassica oleracea var. capitata L.). Indian J. of Agric. Sci. 80 (2): 116-118.

Sudjana Briljan, Muharam and Vera Subardja. 2017. Enrichment of mushroom compost heap quality using Azotobacter and Pseudomonas as a renewable ameliorant. International $J$. of Agric. Innovations and Research. 5(5): 2319-1473.

Taha Sahar S., Osama A. Seoudi, Yasser F. Abdelaliem, Mofreh S. Tolba and Shereen S. F. El Sayed. 2018. Influence of bio-spent mushroom compost tea and potassium humate as a sustainable partial alternate source to mineral-N fertigation on tomato. Egypt. J. of Appl. Sci., 33 (1) :2018.

ÜnalMesude, 2015. The utilization of spent mushroom compost applied at different rates in tomato (Lycopersicon esculentum Mill.) seedling production. Emirates Journal of Food and Agriculture. 27(9): 692-697.

Yildirim E. Karlidag H. Turan M. and Donmez M. H. 2009. Potential of use of plant growth promoting rhizobacteria in organic broccoli (Brassica oleraceceae L.) production, www. Ecofruit.net/.

\section{How to cite this article:}

Kedar, A.R., T.K. Narute, S.N. Hasabnis and Potdar, A.R. 2019. Influence of Enriched Button Mushroom Spent Compost on Growth and Yield of Cabbage. Int.J.Curr.Microbiol.App.Sci. 8(11): 1658-1663. doi: https://doi.org/10.20546/ijcmas.2019.811.192 